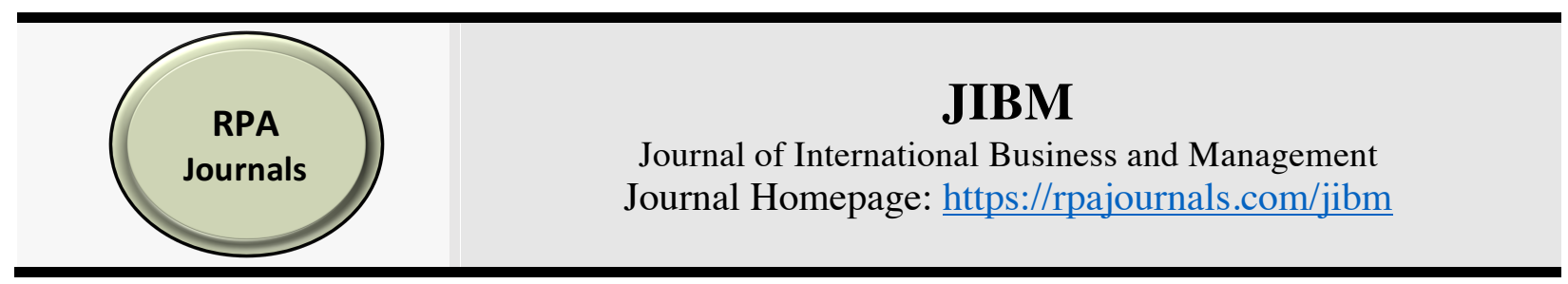

\title{
Social Gender Perceptions of Women Working in the Healthcare Sector in Turkey
}

\author{
Halil DEMIR $^{1 *}$ \\ İsmail Biçer ${ }^{2}$ \\ Istanbul Rumeli University, Turkey ${ }^{1}$ \\ Istanbul Arel University, Turkey ${ }^{2}$
}

\begin{abstract}
The aim of this study is to evaluate the gender perceptions of women working in the health sector. The study was conducted questionnaire method in private health institutions determined by researchers in Istanbul and Ankara. Demographic data were obtained by means of a questionnaire, $\mathrm{t}$-Test and One-Way ANOVA tests were performed. As a result of the research, it was determined that the opinions of the women working in the health sector were not only in the decision of the men in the decisions taken in the family; there is no discrimination between men, girls, and boys.
\end{abstract}

Keywords: Female, Gender, Healthcare Services, Social Gender, Healthcare Workers

*Corresponding author: Halil DEMIR; Email: halil.demir@rumeli.edu.tr

DOI: https://doi.org/10.37227/jibm-2021-01-119

\section{Introduction}

The $17^{\text {th }}$ and $18^{\text {th }}$ centuries are periods of significant political and social dynamism in the world. In these days when capitalism was born and developed, bourgeois revolutions took place; The production, which traditionally continued in the household, has moved from here to the public sphere. In this deep separation between the public and private spheres, women were excluded from production, confined to homes, and pushed into an object of the private sphere (Örs, 2014). In essence, the French Revolution, which stands out with the principle of "people are born equal", is an inspiration for this movement that demands gender equality. With this date, women have now begun to voice their demands to get their share of equality (Tekeli, 2017).

While men are dominant in political, social, and economic life and assume the role of supporters, women are excluded from the social, economic, and political sphere by exalting their unpaid and unpaid labor-based housework, elderly care responsibilities, and maternal roles (Dinçer and Yirmibeşoğlu, 2020). Today, with the equal provision of social education opportunities in many regions of the world, women gain a place in every profession. In the 21 st century, the employment rates of women with children have accelerated with the increase in child care facilities (Blundell et. all, 2020). Also, women 
who make up about half of the global population they work with lower income compared to others (World Bank, 2020). According to the data of 2020, the equivalent of an American dollar male labor working in the same line of work corresponds to $\$ 0.81$ for women (Payscale, 2020). This data clearly reveals the wage inequality between men and women. Economic barriers; social barriers while having children, low paid employment and marriage; It includes thoughts and actions to exclude women from the economic sphere based on low educational level and gender perception in society. Moreover, care work is seen as women's work on the basis of gender and is left to the responsibility of women entirely (Can, 2015). As a result, women find it difficult to balance work-family life. In this context, the aim of the study is to determine the gender perception levels of women working in the health sector and to determine their relationships with demographic variables.

\section{Literature Review}

Today, gender inequalities in the health services workforce in the world have been identified as factors that can cause major problems and are of great importance for the sustainable presentation of the health workforce and health systems. Health services are represented by women in the majority of the specialized health workforce in most OECD countries, and this ratio seems to be increasingly becoming a source of employment (OECD, 2018). Therefore, it would be reasonable to expect a strong and influential presence of women in healthcare decision-making circles, particularly across the spectrum of clinical practice, education, planning, advocacy and policy. However, despite the fact that in some countries $75 \%$ of the global health workforce is made up of women, only about $25 \%$ of these women hold leadership positions (Islam, Jantan, Hashim, Chong, \& Abdullah, 2018). In the healthcare delivery sector, female leaders represent only $18 \%$ of hospital CEOs and $14 \%$ on health management boards; In clinical leadership, this ratio is only $15.9 \%$ of women who have reached senior positions; In another field, academic medicine, only $14 \%$ of women pursuing a high-level career reached Class A (Kalaitzi et al., 2019).

Cultural and socio-economic contexts, often intensified by unfortunate economic or social turbulence situations, affect socially accepted perceptions of gendered authority and leadership that have been legitimized at both the community and professional level; provided that these perceptions are deeply rooted, the process of permanence and transferability may hinder the course of change that is often needed in modern societies (Helman, 2007; Kalaitzi et al., 2019). When we evaluate it in terms of gender diversity, it is at the top of the agenda in the business and labor world. The subject is generally discussed from two angles. One of the most important issues on the agenda politically shows the fact that the female half of the population is underrepresented in leadership roles and unequal pay is unfair and unfair. (Gatrell and Swann, 2008; Islam, Bin Zantan, \& Saimoon, 2017). When evaluated in terms of its economic dimension, it is observed that organizations with a balanced distribution in terms of gender have higher efficiency levels. (Wittenberg-Cox, 2010). In addition, it shows that especially gender and management issue is among the important research topics recently (Joshi et al., 2015; Vanderbroeck and Wasserfallen, 2017).

Worldwide, the role of women in corporate governance has been considerable over the past two decades, and in addition, women have been employed in senior and middle management positions at a high level worldwide. For example, the company assumed the presidency of the women (13.3\% in Norway) and (11.1\% in Turkey), whereas the other hand, women are serving as senior executives (59.3\% in Jamaica), (42.7\% in the USA) and (34.2\% in the United Kingdom). This situation gives hopeful signals that it may improve day by day. (ILO, 2015). Until now, gender / gender differences among health sector workers serving in 
various countries regarding employment status, positions and wages have been the subject of many studies (George, 2008). Estimates from the survey results show that female employees dominate the health and social work workforce; and research conducted in 104 countries revealed that women provide services at a rate of $70 \%$ in the health workforce. In addition, when the same study is evaluated in terms of job situations and job distributions that vary by gender: it was observed that men are generally in pharmacy, medicine and dentistry positions, and women are in nursing and midwifery jobs (Boniol et al., 2019). Although recent reports show a high increasing trend among women providing healthcare, they also face discrimination and pay inequalities of up to $30 \%$ compared to their male counterparts (Habib et al., 2020).

The concept of gender role has become very popular in the last fifteen years. The plays, scientific writings, pedagogical methods and political discourse that people play are based on the existence of this role. Before moving on to gender roles, it will be useful to briefly mention the distinction between Illich's gender role and gender. According to Illich, many people think the gender role is less variable. However, whether you like it, whether you have a gender role, whether you accept it or not, or whether you are offended or offended, is different from gender. Something to say you're a woman or a man. Whether you're a man, a woman, or a person, it's something completely different. Human beings are born and grown up in sex, something that has been won. Gender expresses integrity in the real world, and no matter how vague and fragile it is, it closes us to the world. Gender, by contrast, means a universe in which there is always more than unlimited openness. (Illich, 1996). Health is important not only for itself, but also because it is a prerequisite for productive participation of women in all spheres of social life. Therefore, there is a close connection between a woman's working life and her health.

When women are examined in working life, it is seen that women still do not play an active role in paid production. The ability to adapt to changes in production and management has been replaced by the cheap workforce priority, which prevailed until yesterday. However, it is seen that the traditional perspective on female labor force expectations still continues. The priorities used by both society and women in self-definition are effective in this regard. To put it more clearly, it is inevitable to define it as cheap labor and auxiliary family workers, as long as the primary role of society and women is "spouse and mother ve and this has a natural consequence as a housewife (Minibaş, 1998).

While men make extensive use of social and economic resources, women benefit more from these opportunities. This leads to inequality between men and women. This inequality is evident in the distribution of income and wealth. About $70 \%$ of the poor people in the world are women. Feminisation of poverty was determined in both rich and poor countries. This shows women's unequal position in the labor market, less positive treatment in many social security systems, and low status in the family (WHO, 1998).

It is the basic element and driving force of development in terms of women's functions and responsibility area. It controls a large part of the non-monetary economy in its domestic and foreign activities and has an important share in the monetary economy. Unbalanced increasing population, high infant and child mortality, low economy, inefficient agricultural activity, deteriorating environment, double structure and widespread low quality of life affect women and children more. As a result, women have to deal with unequal opportunities, higher risks and a life determined by those who do not have their own preferences. However, investments in women will make them aware and choose among the new opportunities created. While it is not possible to find solutions to all kinds of problems by investing in women, it will provide a basis for better generations and opportunities for 
future generations by reducing the gender gap in the development of communities and accelerating structural change (Adak, 2015). In a society, if a woman's education level is low, it is impossible to think that she is healthy in such a society, she has no job for wages.

\section{Research Method}

In this section, hypotheses, universe and sample, data collection tool, data collection method and analysis method are mentioned. Test results, findings and hypothesis results were evaluated.

\section{Scope of Research And Hypotheses}

The aim of this study is to evaluate gender perceptions of women working in health sector in terms of their characteristics such as age, education, income, occupation and sector experience. Within the scope of the study, demographic information of the women participating in the survey was evaluated with gender perception.

$\mathrm{H}_{1}=$ There is a significant difference between age and gender perception.

$\mathrm{H}_{2}=$ There is a significant difference between educational status and gender perception.

$\mathrm{H}_{3}=$ There is a significant difference between profession and gender perception.

$\mathrm{H}_{4}=$ There is a significant difference between income and gender perception.

$\mathrm{H}_{5}=$ There is a significant difference between the total working years and gender perception in the sector.

\section{Research Population And Sample}

The research was conducted on women working in private hospitals in Istanbul. The researchers identified four private hospitals with 250 or more staff. Required permissions have been received. A total of 874 women were employed. 387 questionnaires with valid and incomplete information were analyzed. In cases where the universe size is 750 or more, the sample size calculated for the sampling error $\alpha=0.05$ is 254 (Yazıcıoğlu and Erdoğan, 2004). In this study, sample size is sufficient. The rate of reaching the universe is $44.27 \%$. Data were collected in March-April 2019 because access to the entire universe is limited over time.

\section{Data Collection Method}

The questionnaire was used as a data collection tool. The first part of the questionnaire contains demographic characteristics prepared by the researchers. In the second part of the questionnaire, Gender Perception Scale which was adapted to Turkish in 2013 by Altınova and Duyan, was tested for validity and reliability. The scales were added to the questionnaire with demographic questions without any change. The Gender Perception Scale is scored in a 5-point Likert style (1 (completely disagree), 2 (disagree), 3 (undecided), 4 (agree), 5 (fully agree)).

\section{Method of Analysis}

SPSS 22 program was used in the analysis of the data obtained from the questionnaires. Number, percentage, mean and standard deviation, which are descriptive statistical methods, were used in the evaluation of the data. As a different sample group was used from the original scale development study, explanatory factor analysis and reliability analysis were performed to test the validity and reliability of the scale. ANOVA test was used to test the hypotheses. 


\section{Findings}

All participants were women. When the education levels of the participants were examined, $25.8 \%$ of them were high school, $40.8 \%$ were associate degree and $33.3 \%$ were undergraduate. In addition, $57.9 \%$ of women are in the $19-24$ age group, $19.6 \%$ are in the $25-30$ age group, $14 \%$ are in the $31-36$ age group, and $8.5 \%$ are over 37 years of age. $27.9 \%$ of the women are nurses, $26.6 \%$ are medical secretaries, $28.4 \%$ are patient consultants and $17.1 \%$ are administrative staff.

Table 1: Table 1 shows the distribution of demographic features such as income and total working years in the health sector.

\begin{tabular}{|c|c|c|c|}
\hline \multicolumn{2}{|l|}{ Demographic Features } & \multirow{2}{*}{$\begin{array}{c}\mathbf{n} \\
224\end{array}$} & \multirow{2}{*}{$\begin{array}{c}\text { Percentage (\%) } \\
57.9\end{array}$} \\
\hline & $19-24$ & & \\
\hline & $25-30$ & 76 & 19.6 \\
\hline Age & $31-36$ & 54 & 14 \\
\hline & 37 and above & 33 & 8.5 \\
\hline \multirow{3}{*}{ Education } & High school & 100 & 25.8 \\
\hline & Associate Degree & 158 & 40.8 \\
\hline & Bachelor's Degree & 129 & 33.3 \\
\hline \multirow{4}{*}{ Profession } & Nurse & 108 & 27.9 \\
\hline & Medical Secretaryship & 103 & 26.6 \\
\hline & Patient Advisor & 110 & 28.4 \\
\hline & Administrative Personnel & 66 & 17.1 \\
\hline \multirow{5}{*}{ Health Sector Working Year } & 1 year and less & 89 & 23 \\
\hline & $1-3$ year & 116 & 30 \\
\hline & 3-5 year & 91 & 23.5 \\
\hline & $5-7$ year & 36 & 9.3 \\
\hline & 7 year and above & 55 & 14.2 \\
\hline \multirow{6}{*}{ Income } & $2000-2500$ & 73 & 18.9 \\
\hline & $2501-3000$ & 78 & 20.2 \\
\hline & $3001-3500$ & 113 & 29.2 \\
\hline & $3501-4000$ & 44 & 11.4 \\
\hline & $4001-4500$ & 60 & 15.5 \\
\hline & 4501 and above & 19 & 4.9 \\
\hline
\end{tabular}

Despite the validity and reliability of the scale, Kaiser-Meyer-Olkin (KMO) and Bartlett factors Sphericity Test were used to determine whether the data set was suitable for factor analysis. KMO value is expected to take a value between 0 and 1 and exceed 0.60 (Büyüköztürk, 2018). The scale consists of 25 questions. As a result of the tests, the KMO value of the scale was found to be 0.888 and the scale was found to be suitable for factor analysis. After determining the suitability for factor analysis, basic components analysis was performed with 25 items without defining dimensions. In addition, varimax vertical rotation factor structure was analyzed to obtain conceptual significance and increase conceptual significance. The factor analysis results of the 25 -item scale revealed $59.19 \%$ of the total variance and had an eigenvalue greater than 1 . 
Table 2: Despite the validity and reliability of the scale, Kaiser-Meyer-Olkin (KMO) and Bartlett factors Sphericity Test were used to determine whether the data set was suitable for factor analysis.

$\begin{array}{lll}\text { Kaiser-Meyer-Olkin Test (KMO) } & & 0.888 \\ \text { Bartlett's Sphericity Test } & \text { Chi-square } & 4412.574 \\ & \text { Degrees of Freedom } & 300 \\ & \mathrm{P}^{*} & .000\end{array}$

*Statistically significant $(\mathrm{p}<0.01)$

In the interpretation of alpha coefficients, Hair et al. (1998) reference ranges were used. Accordingly, Cronbach's Alpha value $(\alpha) 0.80$ and above is highly reliable, and 0.60 to 0.80 is considered to be highly reliable. Table 3 shows the reliability coefficients of the scale. The scale was found to be quite reliable.

Table 3: It shows the reliability coefficients of the scale (Cronbach's Alpha). The scale was found to be quite reliable.

After testing the normality of the distribution, it was found that the requirements were met and the distributions were normal. ANOVA test was performed for variables with more than two options in normal distributions. In all groups, variance homogeneity test $p$ values were higher than 0.05 and found to be suitable for ANOVA test. The hypotheses created within the scope of the research were tested and all hypotheses were accepted. Age, education, income, occupation and experience of working women were found to be statistically significant in gender perception. Information about the test is given in Table 4. Scheffe Post Hoc Test results were taken into consideration in determining the differences between the groups. There was a significant difference between women in the 19-24 age group and women in the 25-30 age group. A significant difference was found between high school graduates and associate and graduate graduates in terms of education level. There was a significant difference between nurses and medical secretaries in the chosen occupational group and patient counselors. There was no significant difference between administrative staff and profession.

Table 4: ANOVA test was performed for variables with more than two options in normal distributions.

\begin{tabular}{lllllll}
\hline Variables & Variance Source & Sum of Squares & $\begin{array}{c}\text { Degrees of } \\
\text { Freedom }\end{array}$ & $\begin{array}{l}\text { Average } \\
\text { Squares }\end{array}$ & F & p
\end{tabular}

\begin{tabular}{lllllll}
\hline Age & Between groups & 2.069 & 3 & 0.690 & 3.447 & $\mathbf{0 . 0 1 7}$ \\
\hline
\end{tabular}




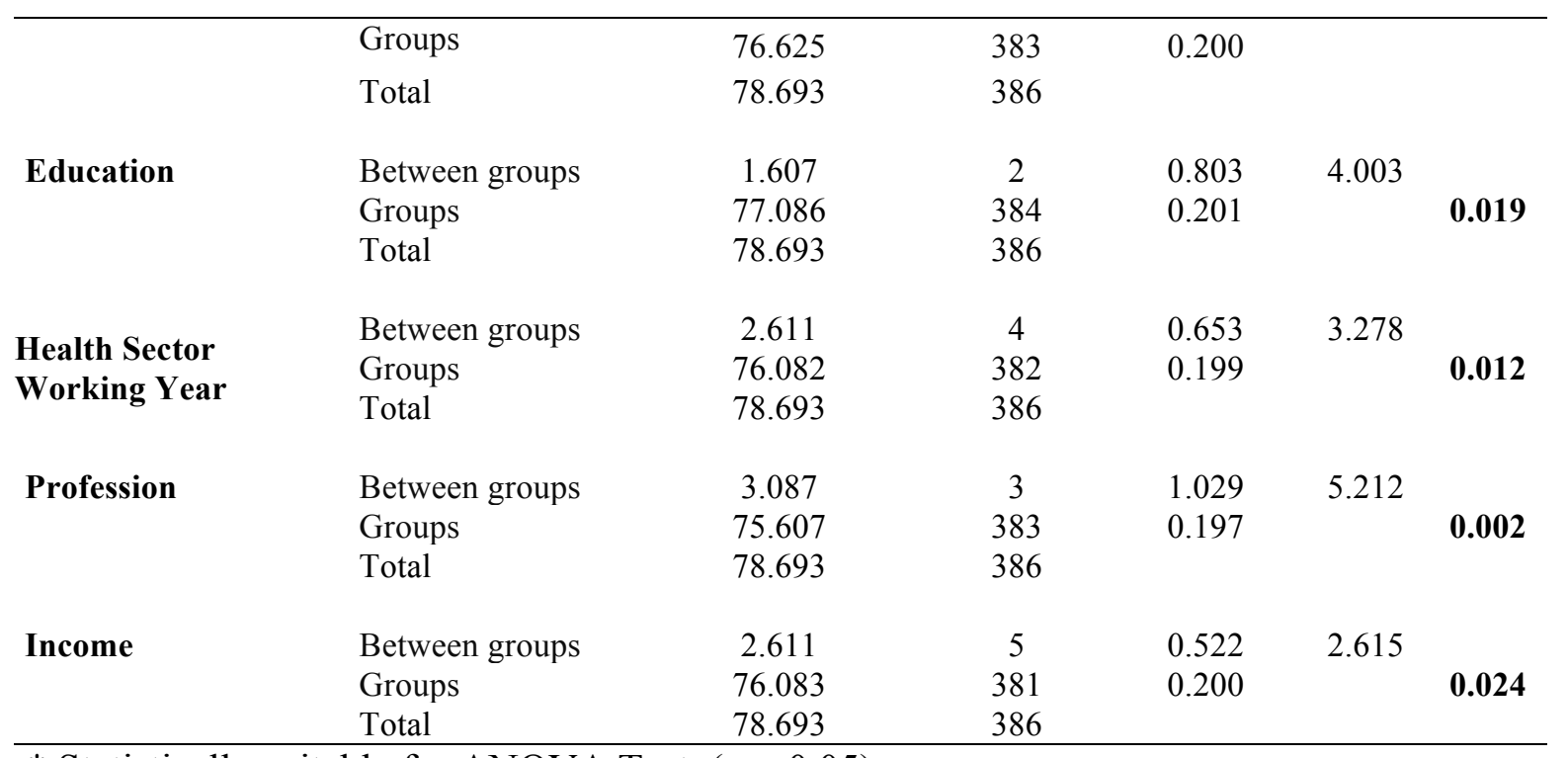

* Statistically suitable for ANOVA Test $(\mathrm{p}<0.05)$.

The mean scores of the participants' scores on the Gender Perception Scale items are shown in Table 5. According to this table, it is seen that the overall average scores of the scale expressions are above 3 . The majority of women think that marriage does not prevent women from working, that women can be managers, and that working women enjoy life more. In addition, the woman should not earn more money from her husband, the idea that the woman should give money to her husband and the family should be working only in cases of economic difficulties, such as the idea that women do not participate.

Table 5: The mean scores of the participants' scores on the Gender Perception Scale items are shown in this table. According to this table, it is seen that the overall average scores of the scale expressions are above 3 .

\begin{tabular}{llll}
\hline & \multicolumn{1}{c}{ Scale Items } & Average & $\begin{array}{c}\text { Standard } \\
\text { Deviation }\end{array}$ \\
\hline 1 & Marriage doesn't stop her from working. & 1.15 \\
2 & A woman should only work if her family has economic difficulties. & 2.82 & 1.20 \\
3 & Working women can also spare enough time for their children. & 3.43 & 1.11 \\
4 & Women should not work after becoming a mother. & 2.78 & 1.13 \\
5 & Women politicians can also be successful. & 3.72 & 1.12 \\
6 & Women should not work after marriage. & 2.46 & 1.25 \\
7 & Working life does not cause the woman to interrupt the housework. & 3.25 & 1.15 \\
8 & A working woman enjoys life more. & 3.62 & 0.96 \\
9 & Women should always be protected by men. & 3.30 & 1.14 \\
10 & The woman should not work if her husband does not allow it. & 2.71 & 1.12 \\
11 & Women can be managers. & 3.84 & 1.02 \\
12 & A working woman should give her husband the income she earns. & 2.51 & 1.04 \\
13 & A working woman becomes a better mother to her children. & 3.34 & 1.04 \\
14 & Men should also do household chores like washing dishes. & 3.78 & 1.04 \\
15 & A husbandless woman resembles a derelict house. & 2.85 & 1.26 \\
16 & Men must earn a family's income. & 2.85 & 1.18 \\
17 & Women should not open places such as commercial shops (cafes, markets, real & 2.63 & 1.31 \\
& estate agents) on their own. & & 1.20 \\
18 & The first task of women is to undertake household chores. & 2.76 & 1.17 \\
19 & A woman shouldn't make more money than her husband. & 2.44 \\
20 & Men should always be the head of the house. & 2.67 & 1.17 \\
\hline
\end{tabular}




\begin{tabular}{llll}
\hline 22 & Girls should be given as much freedom as boys. & 3.73 & 1.08 \\
23 & A woman should be able to oppose her husband if necessary to have her own & 3.47 & 1.11 \\
rights. & & \\
24 & 2.99 & 1.11 \\
25 & Men should make be younger than her husband. & 2.81 & 1.22 \\
General & 3.08 & 0.45 \\
\hline
\end{tabular}

\section{Discussions}

Within the scope of the study, all participants are women. The education level of the participants was determined as $25.8 \%$ high school, $40.8 \%$ associate degree, and $33.3 \%$ undergraduate. In addition, 57.9\% of women are in the 19-24 age group. Among the healthcare professionals participating in the study, $27.9 \%$ were nurses, $26.6 \%$ were medical secretaries, $28.4 \%$ patient counsellors, and $17.1 \%$ administrative personnel. Within the scope of the study, it was found that women's gender perception was high (overall scale score of 3.08). Some research results are as follows: Marriage cannot prevent a woman from working. Women politicians can be successful. Working women enjoy life more. Women can be managers. Men should help women with housework. Women should be given all the freedoms afforded to men. Women should be able to benefit their wives when necessary to protect their rights. Contrary to these results, other results are also perceived negatively by women. For example, men should always be leaders at home, women's first duty is housework, a woman should not earn more money than her husband, women should not engage in business activities themselves, women should give the money they earn to their spouses, women should not work after marriage, women should not work after becoming mothers.

The hypotheses formed within the scope of the research were tested and all hypotheses were accepted. There is a statistically significant difference between working women's demographic variables such as age, education, income, profession and experience, and gender perceptions. While these results do not show similar results with some studies in the literature, they overlap with some studies. In traditional societies, women are expected to have regulatory roles and men to have decisive roles. In line with these expectations, women socialize towards the private sphere and men socialize towards the public sphere. Women's work as a determinant of socio-economic level affects their children's perception of gender roles (Ersoz, 2012). This proves the idea that gender perception levels of men and women will be different.

It is stated that Turkish society is accepted as patriarchal as there are significant differences in gender role. Men are expected to control the dominant sex and house; the husband is culturally regarded as the ruler of the family and ultimately considered the official authority that women and children must ultimately respond to (Sakalli-Ugurlu, and Beydogan, 2002). However, as a result of the study, it was found that women do not agree with the idea that "men should always be the head of the house" and "men should make important decisions in the family". The woman's husband is only allowed to enter a job or participate in a profession on an "express or implied leave ken, while her husband is allowed to de reasonably contribute to the family budget (Arat, 2003). As a result of the study, "a working woman should give the income she earns to her husband", ler men should provide the income of a family", kadın a woman should not work if her husband does not allow", "a woman should not earn more money than her husband" and respectively. These results do not match some of the results in the literature.

According to the results of the study conducted by Ersoz, (2012), 42.2\% of the men who participated in the study stated that "women cannot be good managers", $41.4 \%$ thought 
that "politics is not for women ve and $8 \%$ of the women defined traditionally as women's field. It is better to work in areas. These results do not match the results of our study. In addition, in a study conducted by Vefikuluçay et al., (2007), the majority of female students stated that politics is mostly the work of men. This result has similar results with the results of our study. Thus, it is seen that women and men have different opinions about management and politics. The same study concluded that "women have more egalitarian value than men". This result is in line with the general result of our study.

One of the criticisms is that women concentrate mostly on work and that housework is mostly women. For example, the fact that men spend four times less time on unpaid care compared to women is interesting in that they show little change in traditional roles (Koray, 2011). In this study, the fact that women do not participate in the idea that "the first task of women is to undertake household chores doğrulan is confirmed by the other results in the literature. As a result of the study, it was found that women thought that a working woman would be a better mother for her children and that working woman could spend enough time with her children and that they should not work after she became a mother. This situation does not match some of the results found in the literature. For example; In the United Kingdom and Germany, 30 percent of women aged 40 are childless, and in the US, one-third of women who have not yet come to senior management do not want children, according to the National Parental Association estimates that women earn \$100,000 or more per year. 49 percent are said to have no children (Folbre, 2008).

It is reported that the average monthly income of women is $17.5 \%$ less than men at the EU level and that women earn 20\% less in seven members, including Greece, Germany, the Netherlands and the UK (EWL, 2010). As a result of the study, women do not agree with the statement that a woman should not make more money than her husband.

\section{Conclusions}

As stated in the National Action Plan on gender equality Although GDSW provides numerous improvements in women's rights in Turkey, in practice satisfying social life of gender equality it is seen that annoying way reflection. Therefore, broader researches should be conducted in which women are the main subject of cultural, political and economic roles. Otherwise, it will be very difficult to achieve the real solutions that are desired in social, private and professional lives for the real equality of women.

This research represents a group of women working in a particular hospital group. This is an important limitation of the research and the research cannot be generalized to all women working in the health sector. These studies can be expanded with larger sample groups in order to generalize to all-female healthcare professionals. Additionally, gender perceptions of working women can be determined not only in the health sector but also in all other sectors by conducting similar research. General recommendations are as follows: Centers to provide consultancy to women who want to participate in employment should be opened by local governments. It should be ensured that home-based work, home employment, and informal sector developments are taken into account in the local labor market analyzes. Local governments should actively cooperate with universities in their provinces in order to analyze the current situation on gender equality. Local governments should prepare gender equality plans in cooperation with development agencies and share these plans with the public. Women working at the managerial level in local governments should increase.

\section{References}

Adak, N. Ö. (2015). Sağlık Sosyolojisi, Kadın ve Kentleşme. Siyasal Kitapevi. 
Altınova, H. H., and Duyan, V. (2013). Toplumsal cinsiyet algısı ölçeğinin geçerlik güvenirlik çalışması. Toplum ve Sosyal Hizmet, 24(2), 9-22.

Arat, Z. F. K. (2003, January). Where to look for the truth: memory and interpretation in assessing the impact of Turkish women's education. In Women's Studies International Forum, 26(1), 57-68.

Blundell, R., Costa Dias, M., Joyce, R., \& Xu, X. (2020). COVID-19 and Inequalities. Fiscal Studies, 41(2), 291-319.

Boniol, M., McIsaac, M., Xu, L., Wuliji, T., Diallo, K., \& Campbell, J. (2019). Gender equity in the health workforce: Analysis of 104 countries.

Buz, S. (2009). Feminist social work practice.Society and Social Work (published by Hacettepe University, Turkey), 20, 53-65 (in Turkish).

Büyüköztürk, Ş. (2018). Sosyal bilimler için veri analizi el kitabı. Pegem Atıf İndeksi, 001214.

Can, Y. (2015). Ücretli Bir İşte Çalışmanın Kadının Sosyal Konumuna Etkisi. Academic Review of Economics \& Administrative Sciences, 8(2).

Çamur Duyan, G. (2010). Feminization of poverty: An example of Altindag Region of Ankara.Family and Society (published by Ministry of Family and Social Policies, Turkey). 6, 19-29 (in Turkish).

Çelik, Ö. (2012). Women's human rights movement. Journal of Gazi University Faculty of Economics and Administrative Sciences (published by Gazi University, Turkey), 14,149-170 (in Turkish).

Dinçer, F. C. Y., \& Yirmibeşoğlu, G. (2020). COVID-19'un Ekonomik Etkilerinin Toplumsal Cinsiyet Eşitliği Bağlamında Değerlendirilmesi. Gaziantep Üniversitesi Sosyal Bilimler Dergisi, 19(COVID-19 Special Issue), 780-792.

Ersoz, A. G. (2012). The Role of university education In the determination of gender perception: The case of the Gazi University. Procedia-Social and Behavioral Sciences, 47, 401-408.

EWL (2010), "From Beijing to Brussels: an Unfinished Journey", European Women's Lobby, www.womenlobby.org/

Folbre, N. (2008). Reforming care. Politics \& Society, 36(3), 373-387.

Gatrell, C. and Swan, E. (2008) Gender and Diversity in Management: A Concise Introduction, Sage, London.

GDSW, 2008, General Directorate on the Status of Women (GDSW) National Action Plan: Gender Equality 2008-2013

George, A. J. G. P. H. (2008). Nurses, community health workers, and home carers: gendered human resources compensating for skewed health systems. Global Public Health, 3(S1), 75-89.

Golkarian, G. And Cihangir, Y.(2019). Kıbrıs Türk Toplumunda Kadın.

Habib, R. R., Halwani, D. A., Mikati, D., \& Hneiny, L. (2020). Sex and gender in research on healthcare workers in conflict settings: a scoping review. International Journal of Environmental Research and Public Health, 17(12), 4331.

Hair, J. F., Anderson, R. E., Tatham, R. L., and Black, W. C. (1998). Multivariate Data Analysis (5e éd.).

Helman, C. (2007). Culture, health and illness. CRC press.

Illıch, I. (1996). Gender,(Çev. Ahmet Fethi). Ankara: Ayraç Yayınevi.

ILO (2015) Women in Business \& Management: Gaining Momentum, International Labour Organization, Geneva, Switzerland. 
Islam, M. A., Jantan, A. H., Hashim, H., Chong, C. W., \& Abdullah, M. M. (2018). Factors Influencing Female Progression in Leadership Positions in the Ready-Made Garment (RMG) Industry in Bangladesh. Journal of International Business and Management (JIBM), 1(1), 1-13.

Islam, M. A., Bin Zantan, H., \& Saimoon, A. (2017). Factors affecting females' participation in leadership positions in RMG industry, Bangladesh. International Journal of Scientific and Research Publications, 7(10), 535-542.

Joshi, A., Neely, B., Emrich, C., Griffiths, D., \& George, G. (2015). Gender research in AMJ: an overview of five decades of empirical research and calls to action: thematic issue on gender in management research.

Kalaitzi, S., Cheung, K. L., Hiligsmann, M., Babich, S., \& Czabanowska, K. (2019). Exploring Women Healthcare Leaders' Perceptions on Barriers to Leadership in Greek Context. Frontiers in Public Health, 7, 68.

Koray, M. (2011). Avrupa Birliği ve Türkiye'de "Cinsiyet" Eşitliği Politikaları: SolFeminist Bir Eleştiri. Çalışma ve Toplum Dergisi, 29, 13-53.

Minibaş, T. (1998). Türkiye'nin kalkınma sürecinde kadın işgücü. N. Arat (der.). Aydınlanmanın Kadınları içinde, (s 331).

OECD. Health Workforce Policies in OECD Countries. (2018). Available online at: http://www.oecd.org/health/health- systems/health- workforce- policies- in- oecdcountries- 9789264239517- en.htm (accessed November 29, 2020).

Örs, H. B. (2014). Modern siyasal ideolojiler. İstanbul Bilgi Üniversitesi Yayınları.

Payscale. (2020). The state of the gender pay gap 2020. Avaliable Date: 21.08.2020, https://www.payscale.com/data/gender-pay-gap.

Sakalli-Ugurlu, N., \& Beydogan, B. (2002). Turkish college students' attitudes toward women managers: The effects of patriarchy, sexism, and gender differences. The Journal of psychology, 136(6), 647-656.

Tekeli, Ş. (2017). Feminizmi düşünmek. İstanbul: Bilgi Üniversitesi Yayınları

Vanderbroeck, P., \& Wasserfallen, J. B. (2017). Managing gender diversity in healthcare: getting it right. Leadership in Health Services.

Vefikuluçay, A. G. D., Zeyneloğlu, A. G. S., Eroğlu, K., \& TAŞKIN, L. (2007). Kafkas Üniversitesi son sınıf öğrencilerinin toplumsal cinsiyet rollerine ilişkin bakış açıları. Hacettepe Üniversitesi Hemşirelik Fakültesi Dergisi, 14(2), 26-38.

Wittenberg-Cox, A. (2010). How women mean business: A step by step guide to profiting from gender balanced business. John Wiley \& Sons.

World Bank. (2020). Population, female (\% of total poulation). Avaliable Date: 25.12.2020, https://data.worldbank.org/indicator/SP.POP.TOTL.FE.ZS.

World Health Organization. (1998). Gender and health.

Yazıcıoğlu, Y., and Erdoğan, S. (2004). SPSS uygulamalı bilimsel araştırma yöntemleri. Detay Yayıncılık, Ankara, (s 53). 